\title{
Evaluation of the Performance of Galvanized Steel Support in Construction of Living Wall Systems
}

\section{Fernando B. Mainier, Maria Alejandra Rico Pérez, Leandro V. Pontual, Ana Lucia Torres Seroa da Motta}

Escola de Engenharia, Universidade Federal Fluminense, Niterói, Brazil

Email: fmainier@uol.com.br, mariaalejandra@id.uff.br

How to cite this paper: Mainier, F.B., Pérez, M.A.R., Pontual, L.V. and da Motta, A.L.T.S. (2016) Evaluation of the Performance of Galvanized Steel Support in Construction of Living Wall Systems. Open Journal of Civil Engineering, 6, 566-576. http://dx.doi.org/10.4236/ojce.2016.64047

Received: May 4, 2016

Accepted: September 2, 2016

Published: September 5, 2016

Copyright $\odot 2016$ by authors and Scientific Research Publishing Inc. This work is licensed under the Creative Commons Attribution International License (CC BY 4.0).

http://creativecommons.org/licenses/by/4.0/

\begin{abstract}
Currently, Living Wall Systems (LWSs) are assuming great importance in the built environment, due to environmental and aesthetic advantages, as well as the use of urban residual space and underutilized surfaces of buildings. However, the maintenance and the durability of the materials used have been a challenge for architects and professionals in the field. The aim of this paper is to evaluate the anti-corrosion performance of a steel framing profile, galvanized carbon steel ( $55 \% \mathrm{Al}-\mathrm{Zn})$, a sustainable material with easy assembly, to apply LWS in the hot and humid tropical climate of Niterói (Rio de Janeiro, Brazil). In order to create the conditions of the tests, "X" cut were made in $\mathrm{Al}-\mathrm{Zn}$ coating, sanding, and application of epoxy and glass fiber-reinforced polyester. After the experiments that lasted four months, the 55\% Al-Zn coating was analyzed using Scanning Electron Microscope (SEM) and energy dispersive X-ray spectroscopy (EDS). The results of the tests were promising for the use of this galvanized steel for application as a support for green vertical facades. 55\% $\mathrm{Al}-\mathrm{Zn}$ coatings are recommended for marine atmospheres due to their good anti-corrosion performance.
\end{abstract}

\section{Keywords}

Living Wall System (LWS), 55\% Al-Zn Coating, Steel Framing, Galvanized Steel, Corrosion

\section{Introduction}

According to Mascaró \& Mascaró [1], the shapes that make up the natural landscape should be better exploited in order to create continuity between nature and the built space, producing a gradual transition from purely built, i.e. artificial, to the natural environment through organic nuances. 
The proposal of the use of residual urban space and of underutilized areas of buildings for alternative elements harmonized with nature, looking to encourage the gardens for green roofs and façades, can improve, significantly, the pollution in cities. However, to become quantitative, a replacement of $10 \%-20 \%$ of conventional roofs would be required [2] [3].

In tropical, hot and humid climates, one of the important roles of vegetation is shade, whose purpose is to reduce the heat during the year, in addition to decreasing the surface temperatures of the floors and facades of buildings, as well as reducing heat felt by the residents of the urban environment [1].

As an example of an efficient job in urban green areas, the building of the California Academy of Sciences in the San Francisco Golden Gate Park can be cited, which has a green roof of $10,000 \mathrm{~m}^{2}$, designed by architect Renzo Piano. This allows a pleasant surrounding transition tree landscape and connects the building to the park, absorbing a great part of the incident rainwater per year, equivalent to 14 million liters [4].

Fedrizzi et al. [5] state that the market of furniture for gardens is growing continuously, considering the well-being of industrialized countries, and different materials can be used to produce such furniture. Wood and plastic materials are often used, but they have some disadvantages to be considered, such as: discoloration and degradation by Ultraviolet Radiation (UV), as well as low mechanical resistance in the case of plastic artifacts, while high production costs and high maintenance are associated with wooden artifacts. Metal substrates such as aluminum or coated steel are preferred, especially considering that the mechanical resistance is good. Still, according to Fedrizzi et al. [5], garden furniture is usually exposed to aggressive environments, resulting in damage on the surface that should be avoided, especially for aesthetic reasons.

The purpose of this paper is to evaluate the anti-corrosion performance of carbon steel galvanized support used in the manufacture of green facades.

\section{Living Wall Systems, Definitions and Characteristics}

Living Wall Systems (LWSs) can be defined as a protective envelope element in order to provide better thermal condition in the built environment [6]. LWSs are sometimes called green walls, green façades, vertical vegetation or bio walls [7]. A study of 56 planter boxes on four floors of the Institute of Physics in Berlin showed that they achieved a mean cooling value of $157 \mathrm{kWh}$ per day [8].

The green façade type studied here is separate, which refers to vegetation that grows on a separate structural system, which can be freestanding or attached to wall [7]. In this case, it is a structural system in galvanized carbon steel, shown in Figure 1 and Figure 2.

This paper focuses on the environmental evaluation of galvanized carbon steel, which composes the planter boxes and structure of an LWS, in order to determine whether this type of system responds correctly to the requirements of durability and anticorrosion, in maritime areas like Niteroi, in the state of Rio de Janeiro, Brazil. 


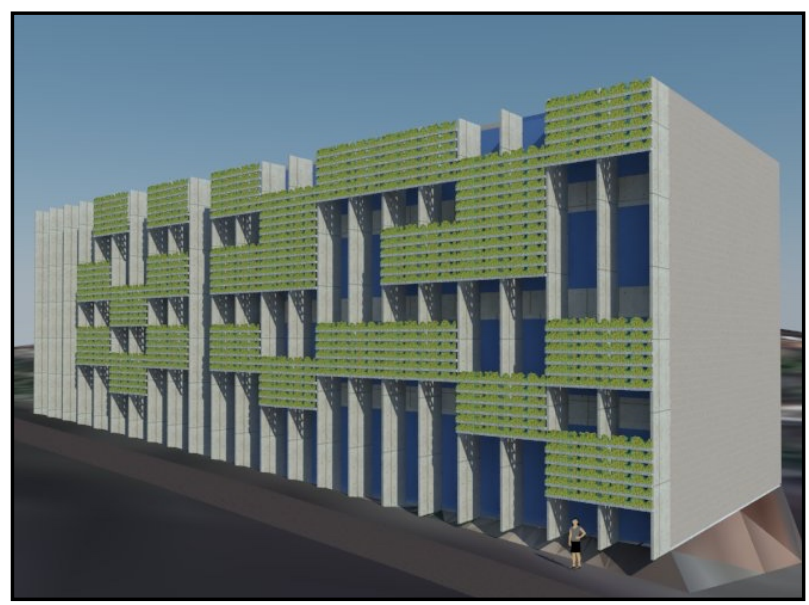

Figure 1. Proposed LWS.

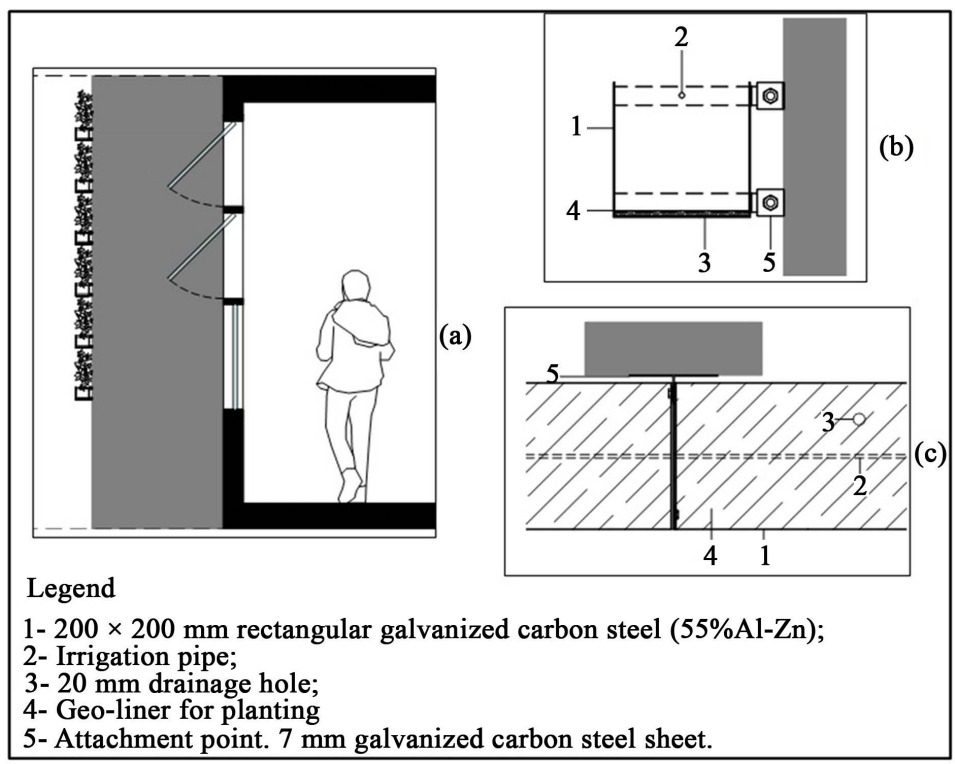

Figure 2. General cross-section of the LWS. (a) Vertical cross-sectional detail; (b) Plan cross-sectional detail; (c) Architectural details not to scale.

\section{Galvanized Carbon Steel Coated with 55 \% Al-Zn}

The advantages of this galvanized steel structure are based, mainly, on the following points: free large spans, allowing flexible spaces, fixing freedom in the building of the walls' structure, and corrosion resistance offered by a $55 \% \mathrm{Al}-\mathrm{Zn}$ coating (hot dip).

The hot-dip process [9] [10] of a coated steel sheet for the formation of Al-Zn coating consists of, first, alkaline cleaning, mechanical cleaning and electrolytic cleaning of the sheet for the removal of oils, grease and possible adhering residues. Later, the sheet is heated and guided, continuously, by rollers to a pot with a molten bath liquid of a metal alloy consisting of $55 \%$ of aluminum, $43.5 \%$ zinc and $1.5 \%$ silicon, as shown in Figure 3. It is important to note that although the coating has $1.5 \%$ silicon ( $\mathrm{Si}$ ), it is commonly known as $55 \% \mathrm{Al}-\mathrm{Zn}, 55 \mathrm{Al}-45 \mathrm{Zn}$, or $55 \mathrm{Al}-\mathrm{Zn}$. 


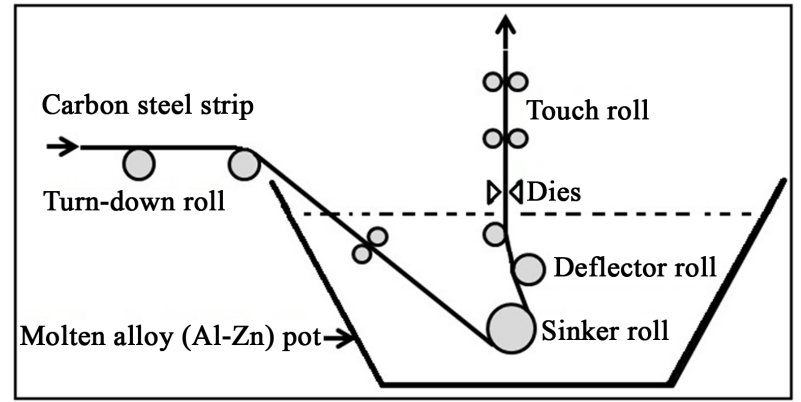

Figure 3. Deposition of galvanized carbon steel ( $55 \% \mathrm{Al}-\mathrm{Zn})$ by hot dip process.

The function of adding silicon is to promote and control the diffusion between the molten Al-Zn alloy and the carbon steel strip during the immersion in the pot to form an intermetallic diffusion layer, consisting of $48 \%$ aluminum, $14 \%$ zinc, $24 \%$ iron and $11 \%$ silicon. The temperature in the pot of the molten metal is approximately $600^{\circ} \mathrm{C}$, and the viscosity of this fused alloy permits a good deposition and adherence on the surface of the carbon steel [9] [11].

Figure 4 shows the deposition model of this process that consists of a layer of Al- $\mathrm{Zn}$ $\mathrm{Si}$ and a layer from of diffusion of metal alloy with carbon steel. This 55\% Al-Zn coating corresponds to an average of $22-24 \mu \mathrm{m}$ thickness, and to an average of 165 - 180 $\mathrm{g} / \mathrm{m}^{2}$ of this alloy. It combines the durability of aluminum with zinc galvanic protection, offering excellent resistance to corrosion in marine, urban and industrial atmospheres.

Given these assumptions, we performed experiments to evaluate the anti-corrosion performance of carbon steel coated with 55\% Al-Zn.

\section{Materials and Methods}

In order to evaluate, experimentally, the performance of carbon steel coated with $\mathrm{Al}-\mathrm{Zn}$ for a green roof, we conducted the experiment shown in Figure 5. It was constructed from a support of carbon steel coated with $55 \% \mathrm{Al}-\mathrm{Zn}$ that was $50 \mathrm{~cm}$ long and $6.5 \mathrm{~cm}$ wide, separated by acrylic plates in five modules with $10 \mathrm{~cm}$ in length.

At the bottom of module 1 was applied a coating of polyester reinforced with fiberglass on the Al-Zn coating; in module 2 was applied an epoxy coating, after full drying took place with a stylus an "X" shaped cut (X-cut technique); in module 3, sanding took place with sandpaper $n^{\circ} 100$ to remove the Al-Zn coating leaving exposed carbon steel; modules 4 and 5 were unaffected.

The thicknesses of the coatings were determined with a magnetic thickness gauge showing the following results: $23 \mu \mathrm{m}$ for $55 \% \mathrm{Al}-\mathrm{Zn}$ coating; $168 \mu \mathrm{m}$ for coating applied to the glass fiber-reinforced polyester, and $52 \mu \mathrm{m}$ for the epoxy coating. The "X" cut has been done on the coating of polyester reinforced with fiberglass and the epoxy coating, as shown in Figure 6.

To evaluate the anti-corrosion performance of 55\% Al-Zn coating in modules 1 - 4 (module 5 was not planted to control the 55\% Al-Zn-coated surface), we planted in 


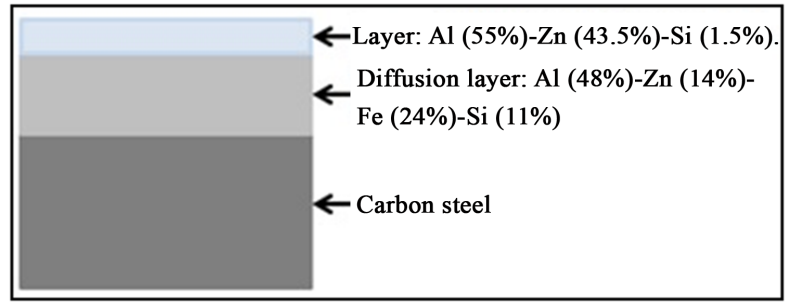

Figure 4. Deposition of a layer of Al-Zn-Si and diffusion layer.

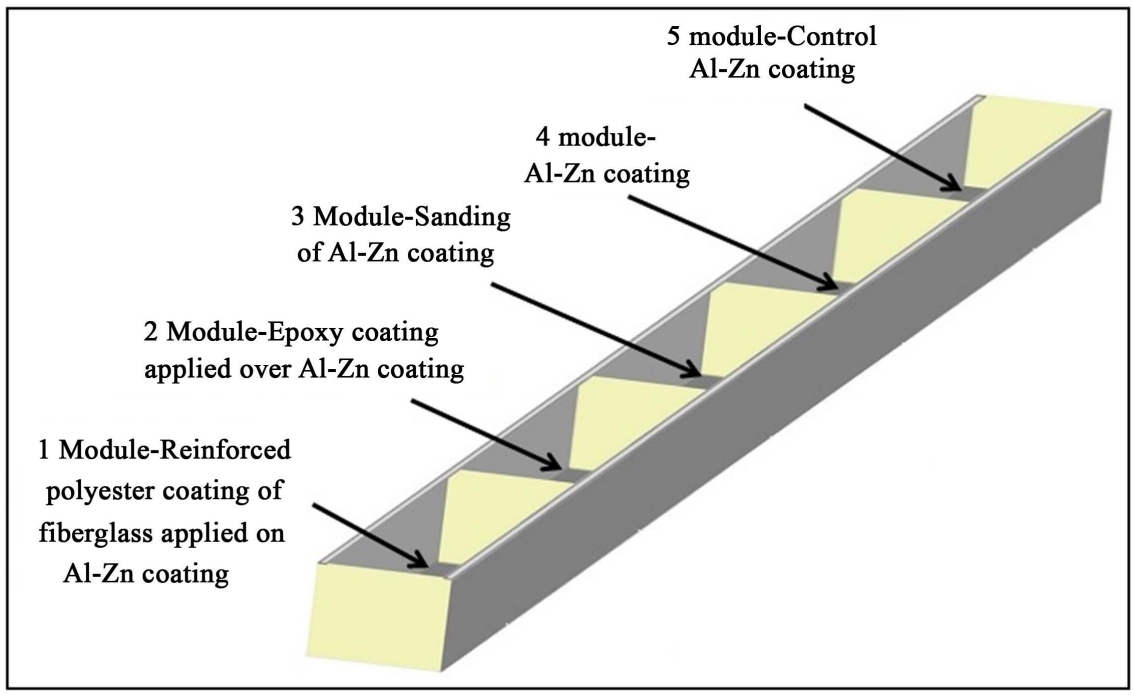

Figure 5. Construction of the experiment from the galvanized steel support.

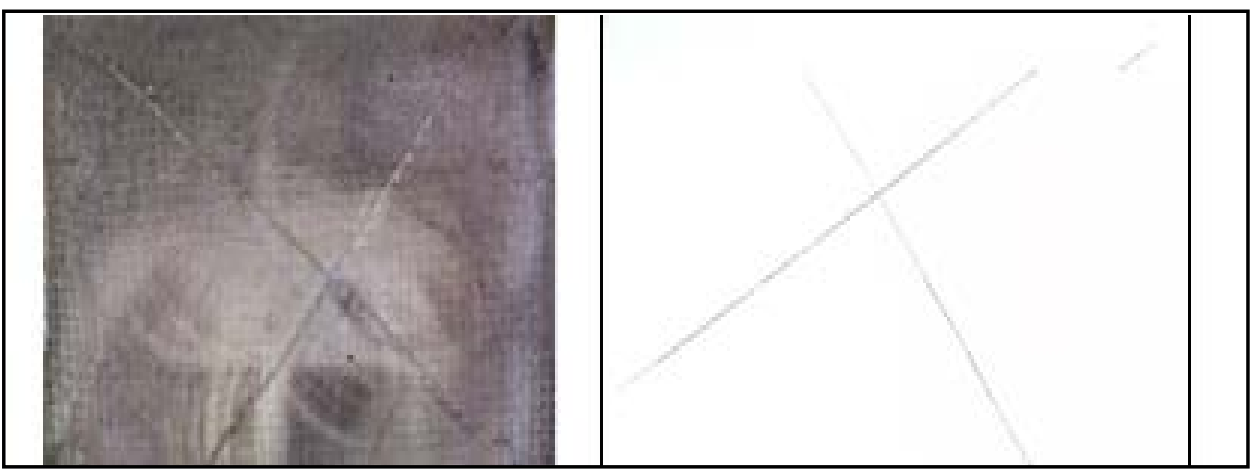

Figure 6. "X" cut on reinforced polyester with fiberglass and epoxy coating. Reinforced polyester with fiberglass (a); Epoxy coating (b).

standard soil a plant resistant to hot climates, named "Flaming Katy" or "Christmas Kalanchoe" (Kalanchöe blossfeldiana) [12], from Madagascar, able to withstand wind and intense Sun (Figure 7). To standard organic soil weighing $75 \mathrm{~g}$, we added $0.2 \%$ of NPK fertilizer $\left(10 \% \mathrm{~N}, 10 \% \mathrm{P}_{2} \mathrm{O}_{5}\right.$, and $\left.10 \% \mathrm{~K}_{2} \mathrm{O}\right)$ and $10 \mathrm{~g}$ coconut fiber, changing the $\mathrm{pH}$ to 4.41 and the average moisture content to $23 \%$. The tests in this condition took four months; after this time, the flowers and soil were removed from the modules (1 4) for evaluation of the Al-Zn coating. 


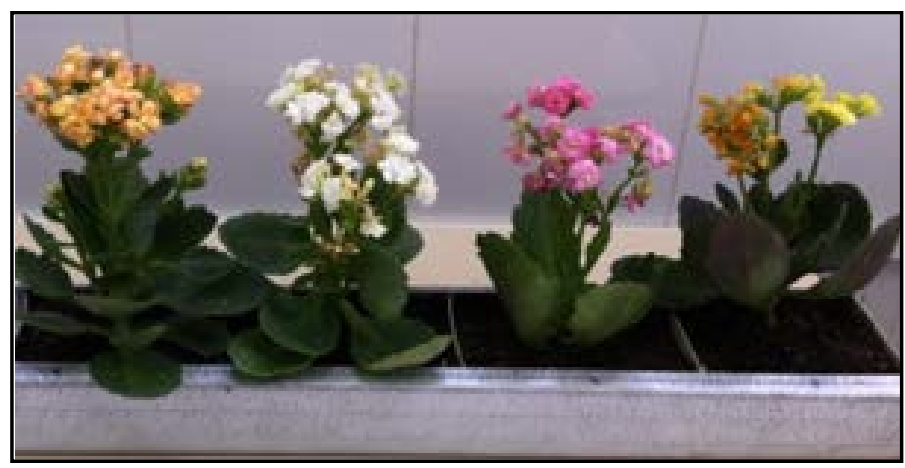

Figure 7. Flaming Katy or Christmas Kalanchoe (Kalanchoe blossfeldiana).

\section{Results and Discussion}

After four months (for modules 1 - 4), the soils with the plants were removed for the determination of the $\mathrm{pH}$ of the soil and corrosion evaluation of the surface from the bottom of each module.

The $\mathrm{pH}$ of the soil presented in Table 1 shows the values determined at the beginning and at the end of the experiment: slight increase of $\mathrm{pH}$ is noted.

Over these four months, the plants showed a decrease in coverage of leaves and flowers, and also the size of the roots. They did not wilt, even having limiting conditions, such as space, the natural insolation insufficient for photosynthesis and the deficiency of drainage, all basic items in the performance of the vegetation in green roofing systems on façades.

In order to evaluate the performance of the materials, we removed samples from the bottom of the experiment (Figure 5) for modules $1-4$.

From the evaluation of modules 1 and 2, respectively, of the application of polyester reinforced with fiberglass and epoxy on the galvanized steel, it can be concluded that such coatings provide overprotection to the galvanized material (the increased thickness of the corrosion barrier). Consequently, there was an increase of the life cycle of the galvanized steel, even under aggressive atmospheric conditions, including marine atmospheres.

In relation to the " $\mathrm{X}$ " cut was made the coatings mentioned in order to create unfavorable conditions $\mathrm{Al}-\mathrm{Zn}$ layer, it was observed by optical and electronic microscopy that the zinc layer provided the cathodic protection needed for carbon steel, not allowing the evolution of applied coatings' corrosion, as shown in the subsequent figures aiming to clarify the mechanisms of corrosion and corrosion protection.

Figure 8 shows two types of cuts in the form of " $\mathrm{X}$ " on the coating of reinforced polyester with fiberglass or epoxy; a cut is considered light and the other is considered deep. The light reaches the diffusion layer, while the deep cut reaches the carbon steel. In both cases, the zinc acts as a galvanic anode, providing the electrons needed for the steel not to be corroded. In this case, there is a passivation on the steel surface preventing or retarding the corrosion reactions. The formation of zinc hydroxide, $\mathrm{Zn}(\mathrm{OH})_{2}$ provides a surface cathode passivation [13] [14]. 


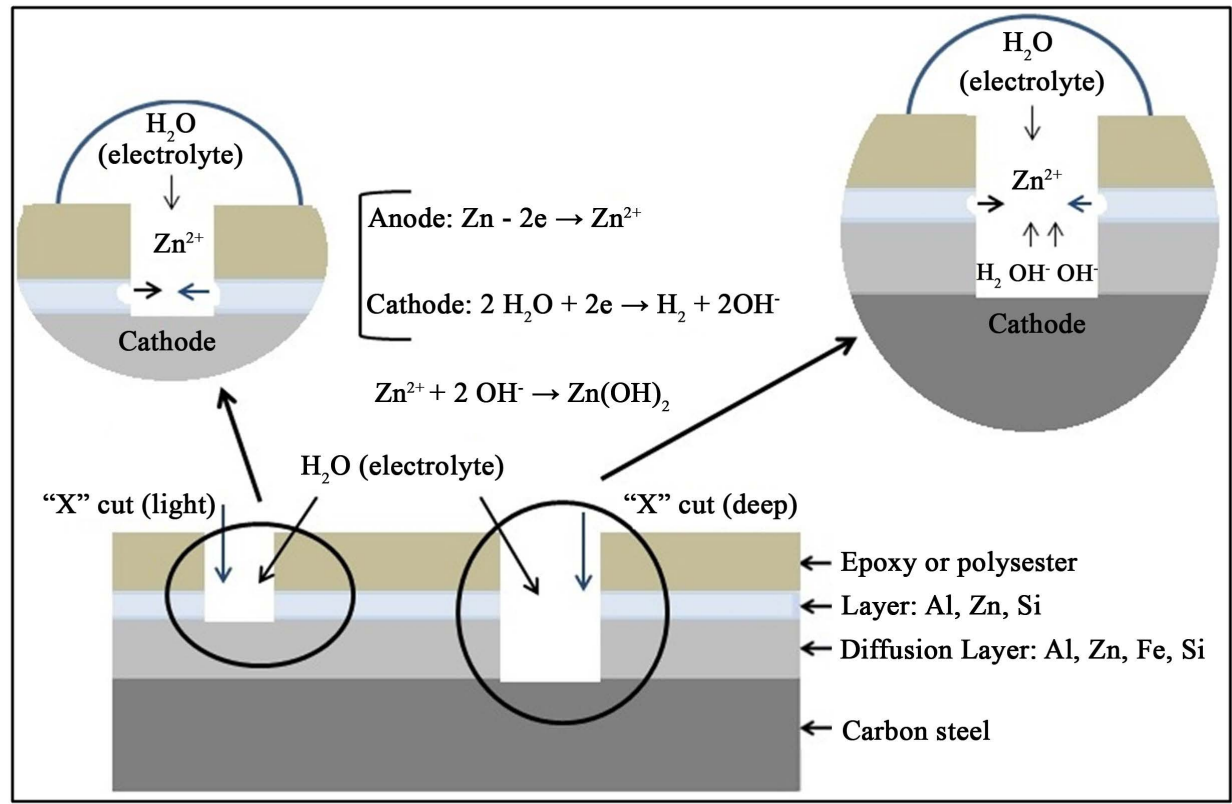

Figure 8. Schematic diagram illustrating the " $X$ " cut performed with a blade over epoxy coating on galvanized steel or polyester.

Table 1. Soil pH before and after the experiments

\begin{tabular}{rcccc}
\hline & 1 Module & 2 Module & 3 Module & 4 Module \\
\hline Initial soil pH & 4.41 & 4.41 & 4.41 & 4.41 \\
Final soil pH & 4.75 & 4.71 & 4.65 & 4.96 \\
\hline
\end{tabular}

Figure 9 shows a scanning electron microscope (SEM) image of the cut made with a blade on the epoxy layer, also reaching the film of $55 \% \mathrm{Al}-\mathrm{Zn}$. The analysis performed in the surroundings of the cut for energy dispersive X-ray spectroscopy (EDS) has identified the presence of zinc hydroxide $\left(\mathrm{Zn}(\mathrm{OH})_{2}\right)$, zinc oxide $(\mathrm{ZnO})$ and aluminum oxide $\left(\mathrm{Al}_{2} \mathrm{O}_{3}\right)$. The formation of $\mathrm{ZnO}$ can be explained by the loss of water represented by the reaction: $\mathrm{Zn}(\mathrm{OH})_{2} \rightarrow \mathrm{ZnO}+\mathrm{H}_{2} \mathrm{O}$.

The iron from carbon steel was not identified, i.e. the cathodic protection of zinc.

Figure 10 presents the development of corrosive process in module 3 after sanding to remove the $55 \% \mathrm{Al}-\mathrm{Zn}$ film. The formation of hydrated ferric oxide $\left(\mathrm{Fe}_{2} \mathrm{O}_{3} \cdot \mathrm{H}_{2} \mathrm{O}\right.$ or $\mathrm{FeO} \cdot \mathrm{OH}$ ) increases with time, and the aggressiveness of the corrosive medium. The electrochemical reactions (anodic and cathodic) representing this occurrence are presented below:

Anodic: $\mathrm{Fe}-2 \mathrm{e} \rightarrow \mathrm{Fe}^{2+}$

Cathodic: $\mathrm{H}_{2} \mathrm{O}+1 / 2 \mathrm{O}_{2}+2 \mathrm{e} \rightarrow 2 \mathrm{OH}^{-}$

$$
\begin{gathered}
\mathrm{Fe}^{2+}+2 \mathrm{OH}^{-} \rightarrow \mathrm{Fe}(\mathrm{OH})_{2} \\
2 \mathrm{Fe}(\mathrm{OH})_{2}+1 / 2 \mathrm{O}_{2}+\mathrm{H}_{2} \mathrm{O} \rightarrow 2 \mathrm{Fe}(\mathrm{OH})_{3} \\
\mathrm{Fe}(\mathrm{OH})_{3} \rightarrow \mathrm{FeO} \cdot \mathrm{OH}+\mathrm{H}_{2} \mathrm{O}
\end{gathered}
$$




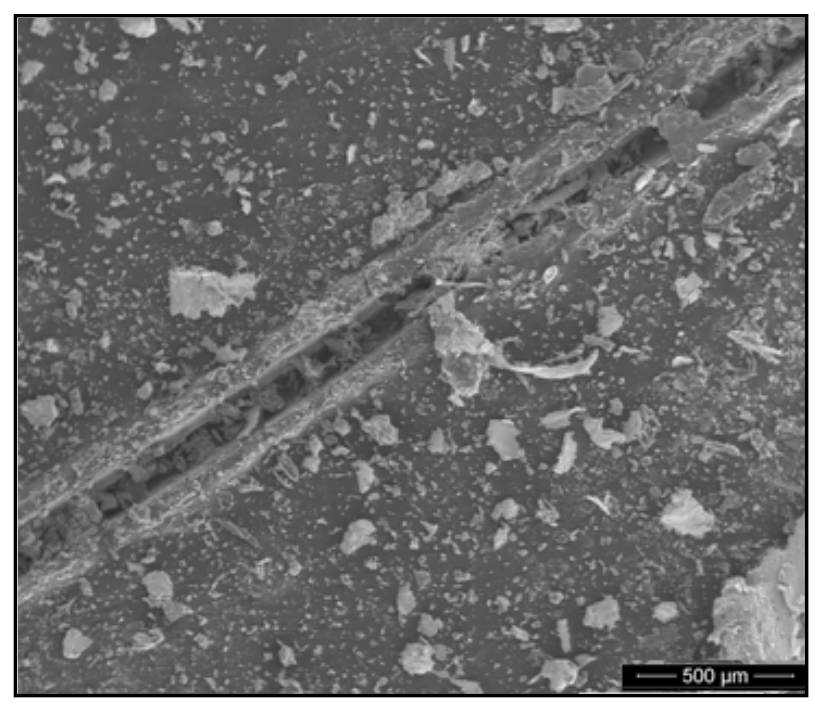

Figure 9. Aspects of the cut in the sample of epoxy coating on galvanized steel.

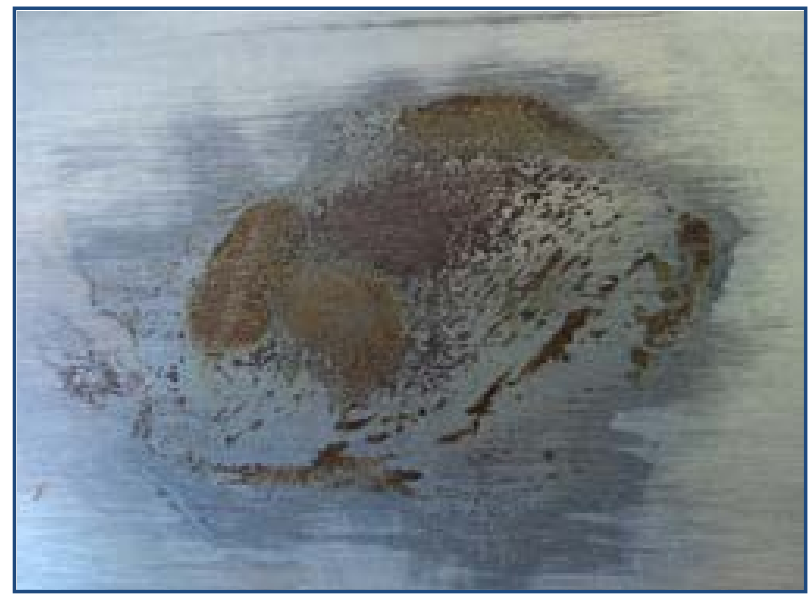

Figure 10. Aspects of galvanized steel sanding with formation of hydrated ferric oxide.

Figure 11, obtained by optical microscopy, shows the formation of a white mass composed of aluminum oxide, zinc hydroxide and zinc oxide. The formation of these compounds could be explained by the galvanic action of aluminum and zinc (i.e. the $\mathrm{Al}-\mathrm{Zn}$ layer) with the following reactions:

Anodic: $\mathrm{Zn}-2 \mathrm{e} \rightarrow \mathrm{Zn}^{2+}$ and $\mathrm{Al}-3 \mathrm{e} \rightarrow \mathrm{Al}^{3+}$

Cathodic: $\mathrm{H}_{2} \mathrm{O}+1 / 2 \mathrm{O}_{2}+2 \mathrm{e} \rightarrow 2 \mathrm{OH}^{-}$

$$
\begin{gathered}
\mathrm{Zn}^{2+}+2 \mathrm{OH}^{-} \rightarrow \mathrm{Zn}(\mathrm{OH})_{2} \\
\mathrm{Zn}(\mathrm{OH})_{2} \rightarrow \mathrm{ZnO}+\mathrm{H}_{2} \mathrm{O} \\
\mathrm{Al}^{3+}+3 \mathrm{OH}^{-} \rightarrow \mathrm{Al}(\mathrm{OH})_{3} \\
2 \mathrm{Al}(\mathrm{OH})_{3} \rightarrow \mathrm{Al}_{2} \mathrm{O}_{3}+3 \mathrm{H}_{2} \mathrm{O}
\end{gathered}
$$

Figure 12 shows an electron microscopic image of the 55\% Al-Zn uniform layer on 


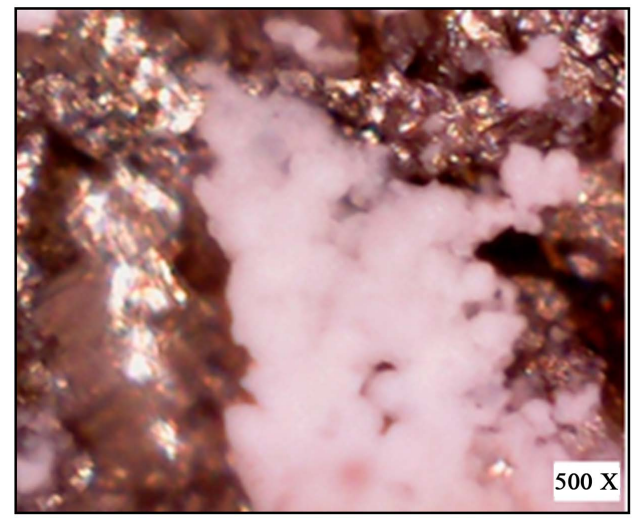

Figure 11. Formation of $\mathrm{Al}_{2} \mathrm{O}_{3}, \mathrm{ZnO}$ and $\mathrm{Zn}(\mathrm{OH})_{2}$ on the surface of galvanized steel.
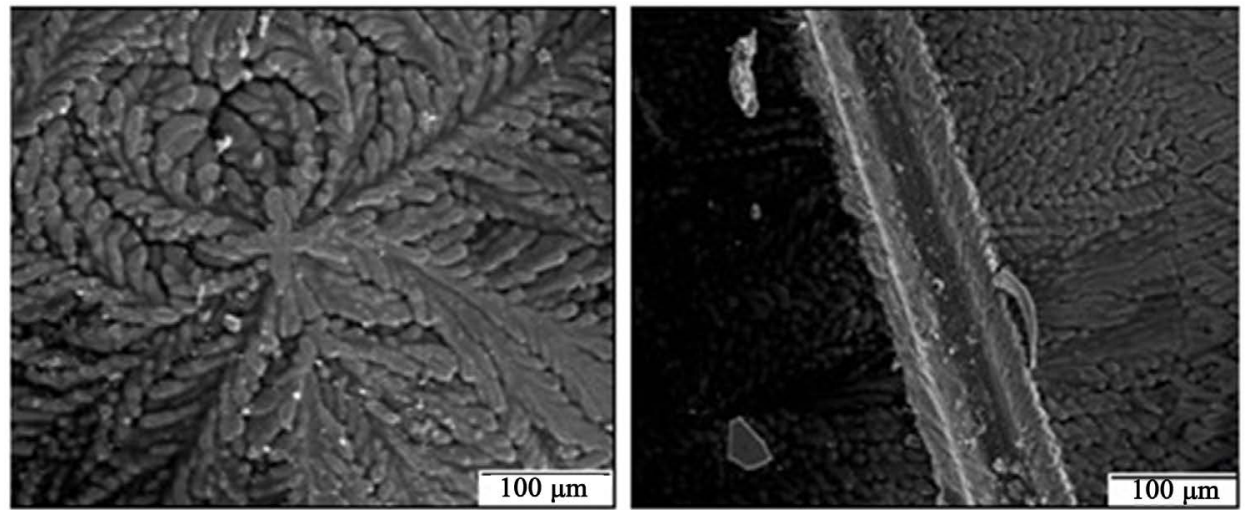

Figure 12. Electron microscopy of Al-Zn layer and the cut made with a steel blade.

the surface of the carbon steel and the cut made with a steel blade. Chemical analysis carried out by Energy Dispersive X-ray Spectroscopy (EDS) on the surface identified the quantitative relation of Al-Zn-Si. We did not observe in this cut any corrosion of carbon steel under this layer.

During a large part of the coating's lifetime, in urban atmospheric conditions, the barrier formed by corrosive products of zinc and aluminum will probably contribute to reducing the rate of corrosion, increasing, consequently, its service life. These facts emphasize that the deep cut in the $55 \% \mathrm{Al}-\mathrm{Zn}$ coating will be protected by this barrier. However, the loss of the coating (sanding) will not give the anti-corrosion protection any longer, and carbon steel corrosion will happen spontaneously. Another important fact established in the experiment is that the application of a $55 \%$ Al-Zn coating will increase corrosion protection and, consequently, the lifetime of the material [15] [16].

\section{Conclusions}

Based on laboratory tests, the following conclusions can be stated:

- The proposed LWS is an easy and quick construction technique. Regarding the durability aspects, the EDS analysis was important to characterize in detailed way for better choice and the protective layers composition; 
- The separate system of green wall that was selected is recommended for maintenance purposes, and also creates a chamber of air that allows the interchange of air in the interior of the space and also in the exterior, at an urban scale;

- The steel framing modular system with LWS combines the technology, the durability of the galvanized materials and the modular characteristics, supporting the credibility of green façades in the constructive environment in Brazil;

- The 55Al-45Zn coating on a carbon steel plate from continuous hot-dip in an Al-Zn bath consists of a layer of $\mathrm{Al}$ (55\%), $\mathrm{Zn}$ (43.5\%), and $\mathrm{Si}$ (1.5\%);

- The Al-Zn layer acts as an efficient galvanic anode protecting the LWS even after scratches, cuts or minor defects that may occur during installation of the green wall;

- The barrier formed by corrosion of Al-Zn and associated with the application of an organic coating (e.g. epoxy or reinforced polyester with fiberglass) increases the time taken to use this material.

\section{Acknowledgements}

The authors are grateful to the LEMMA-UFF (Laboratório de Energia, Materiais e Meio Ambiente), INT (Instituto Nacional de Tecnologia) and CAPES (Centro de Aperfeiçoamento de Pessoal de Nível Superior).

\section{References}

[1] Mascaró, L. and Mascaró, J.J. (2009) Ambiência urbana (Urban Ambience). Masquatro Editora, Porto Alegre (in Portuguese).

[2] Minke, G. (2004) Techos verdes, Planificación, ejecución y concejos prácticos. Editorial Fin de Siglo, Montevideo, $85 \mathrm{p}$.

[3] Minks, V. (2013) A rede de design verde urbano-uma alternativa sustentável para megacidades? (The Green Urban Design Network a Sustainable Alternative for Megacities?). Revista Labverde, 7, 121-141 (in Portuguese).

[4] Piano, R. (2008) California Academy of Sciences. http://www.archdaily.com/6810/california-academy-of-sciences-renzo-piano/

[5] Fedrizzi, L., Rodriguez, F.J., Rossi, S. and Deflorian, F. (2003) Corrosion Study of Industrial Painting Cycles for Garden Furniture. Progress in Organic Coatings, 46, 62-73. http://dx.doi.org/10.1016/S0300-9440(02)00192-3

[6] Loh, S. (2008) Living Walls-A Way to Green the Built Environment. BEDP Environment Design Guide, 1, 1-7.

[7] Matheus, C., Caetano, F.D.N., Morelli, D.D.O. and Labaki, L.C. (2016) Desempenho térmico de envoltórias vegetadas em edificações no sudeste brasileiro (Thermal Performance of Green Envelopes in Buildings in the Brazilian southeast). Ambiente Construído, 16, 71-81 (in Portuguese). http://dx.doi.org/10.1590/s1678-86212016000100061

[8] Schmidt, M., Reichmann B. and Steffan, C. (2007) Rainwater Harvesting and Evaporation for Stormwater Management and Energy Conservation. Berlin State Department for Urban Development.

http://www.gebaeudekuehlung.de/SchmidtReichmannSteffan-Urbenviron-Berlin.pdf

[9] Jordan, C.E. and Marder, A.R. (1997) Fe-Zn Phase Formation in Interstitial-Free Steels hotDip Galvanized at $450^{\circ} \mathrm{C}$ : Part I 0.00 wt\% Al-Zn Baths. Journal of Materials Science, 32, 
5593-5602. http://dx.doi.org/10.1023/A:1018680625668

[10] Feliu, S. and Barranco, V.X.P.S. (2003) XPS Study of the Surface Chemistry of Conventional Hot-Dip Galvanized Pure Zn, Galvanneal and Zn-Al Alloy Coatings on Steel. Actamaterialia, 51, 5413-5424. http://dx.doi.org/10.1016/S1359-6454(03)00408-7

[11] ASM International Handbook Committee, Ed. (1994) ASM Handbook: Surface engineering, Vol. 5. ASM International, Ohio.

[12] Schwabe, W.W. (1985) Kalanchoe blossfeldiana. Handbook of Flowering, 3, 217-235.

[13] Mainier, F.B., Leta, F.R. and Feliciano, F.F. (2014) Application of Anticorrosive Techniques Compatible with the Environment to Engineering Education. American Journal of Environmental Engineering, 4, 176-181. http://dx.doi.org/10.5923/j.ajee.20140406.06

[14] Roberge, P.R. (2000) Handbook of Corrosion Engineering. McGraw-Hill, New York.

[15] Palma, E., Puente, J.M. and Morcillo, M. (1998). The Atmospheric Corrosion Mechanism of 55\% Al-Zn Coating on Steel. Corrosion Science, 40, 61-68. http://dx.doi.org/10.1016/S0010-938X(97)00112-1

[16] Wallinder, I.O., Leygraf, C., Karlen, C., Heijerick, D. and Janssen, C.R. (2001) Atmospheric Corrosion of Zinc-Based Materials: Runoff Rates, Chemical Speciation and Ecotoxicity Effects. Corrosion Science, 43, 809-816. http://dx.doi.org/10.1016/S0010-938X(00)00136-0

\section{Submit or recommend next manuscript to SCIRP and we will provide best service for you:}

Accepting pre-submission inquiries through Email, Facebook, LinkedIn, Twitter, etc.

A wide selection of journals (inclusive of 9 subjects, more than 200 journals)

Providing 24-hour high-quality service

User-friendly online submission system

Fair and swift peer-review system

Efficient typesetting and proofreading procedure

Display of the result of downloads and visits, as well as the number of cited articles

Maximum dissemination of your research work

Submit your manuscript at: http://papersubmission.scirp.org/ 